\title{
VALUE ENGINEERING APPLICATIONS FOR MANAGING SUSTAINABLE INTERMODAL TRANSPORTATION INFRASTRUCTURE ASSETS
}

\author{
Waheed Uddin \\ Center for Advanced Infrastructure Technology (CAIT), University of Mississippi, U.S.A. \\ Corresponding author: \\ Waheed Uddin \\ Center for Advanced Infrastructure Technology (CAIT) \\ University of Mississippi \\ MS 38677-1848, U.S.A. \\ phone: +1 (662) 915-5363 \\ e-mail: cvuddin@olemiss.edu
}

Received: 15 December 2012

Accepted: 5 February 2013

\begin{abstract}
Frequent gridlocks and traffic jams during the periods of rush hours can result in long user delays and more vehicle emissions causing continuous degradation of air quality. The builtinfrastructure of densely populated cities and intercity travel by passenger and freight traffic lead to significant adverse impacts of traffic congestion on air quality, greenhouse gas emissions, and global warming. Transportation contributes $28 \%$ of energy related greenhouse gas emissions in the U.S. This paper shows that traffic related carbon dioxide $\left(\mathrm{CO}_{2}\right)$ emissions are higher per capita for several rural and smaller cities compared to large urban areas in the United States. Inadequate use of mass transit, urban sprawl, construction of more roads and traditional stop-controlled intersections, and addition of more lanes to increase traffic capacity and ease congestion, are primary causes of significant vehicle emission inventory of $\mathrm{CO}_{2}$ and air quality degradation. It is shown that sustainable traffic management policies, such as reduction of work-related travel by cars and more use of mass transit modes, can decrease $\mathrm{CO}_{2}$ emissions. Case studies of value engineering applications are presented to select cost-effective less polluting mass transport strategies based on economic evaluation of life cycle costs and benefits.
\end{abstract}

KEYWORDS

Economic Evaluation, Infrastructure Assets, GHG Emission, Socio-economic, Sustainable, Transportation, Life Cycle, Mass Transit, PRT, Value Engineering.

\section{Introduction}

\section{Roles of cities and intermodal transport for sustaining socio-economic growth}

The efficient public mobility, workplace commute, delivery of goods, access to consumer services, creation of new businesses, job growth, and emergency management during disasters, all depend on efficient and safe transportation infrastructure assets [1]. Similarly, freight traffic and global supply chain inventory management system stakeholders depend on a smooth seamless flow of freight through interconnecting shipping ports, airports, rails, and roads. A recent report by the National Academies [2] shows that U.S. companies collectively spend a trillion dollars a year on freight logistics. This is nearly $10 \%$ of the nation's Gross Domestic Product (GDP). The report states that considering that about $80 \%$ of the population works and lives in cities and urban areas in the U.S, $65 \%$ of goods originate or terminate in cities as per a recent commodity flow survey by the U.S. Department Of Transportation (DOT) [2]. These statistics are indicative of the contribution of cities and importance of the lifeline supply chain to support our society and daily life.

This built-environment of cities and inter-city transport infrastructure leads to significant adverse impacts on traffic congestion and air quality, Green House Gas (GHG) emission, climate change, and nat- 
ural disaster hazards on urban sustainability, mobility, and quality of life. The environment and energy resources are greatly impacted by growth of cities and landuse practices, transportation system planning, managing travel demand and traffic operations, and modal share of trips. Anthropogenic $\mathrm{CO}_{2}$ emission is a major contributor to GHG and global warming. Transportation contributes $28 \%$ of energy related GHG emissions in the U.S. As of 2007 the U.S. transportation sector included over 254 million road transport vehicles which comprised of $93.3 \%$ cars and other automobiles, $2.8 \%$ motorcycles, $0.3 \%$ buses, and $3.6 \%$ trucks [3]. However, trucks on average travel almost twice as much as cars per vehicle per year, consume 3-4 times more fuel than cars per vehicle, and produce both harmful pollution and GHG emissions, as shown by modal comparison in Fig. 1. Freight trucks produce six times more pollution than freight rail (Fig. 2). The growth in passenger travel, freight demand, and traffic congestion directly contributes to increases in mobility costs, user operating costs, air pollution and GHG emissions, public health costs, and other societal costs. Congestion also causes wastage of fuel and stress on commuters.

(Data credit: European Environment Agency/Allianz, SE)

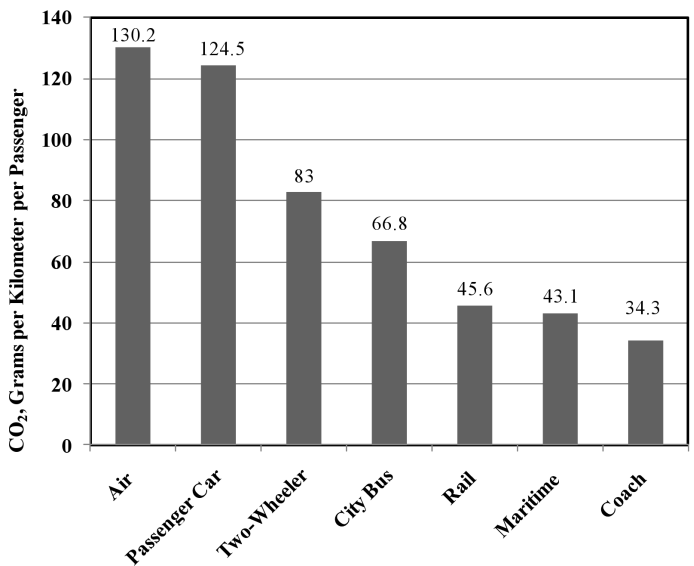

Fig. 1. Modal comparison of passenger transport emissions.

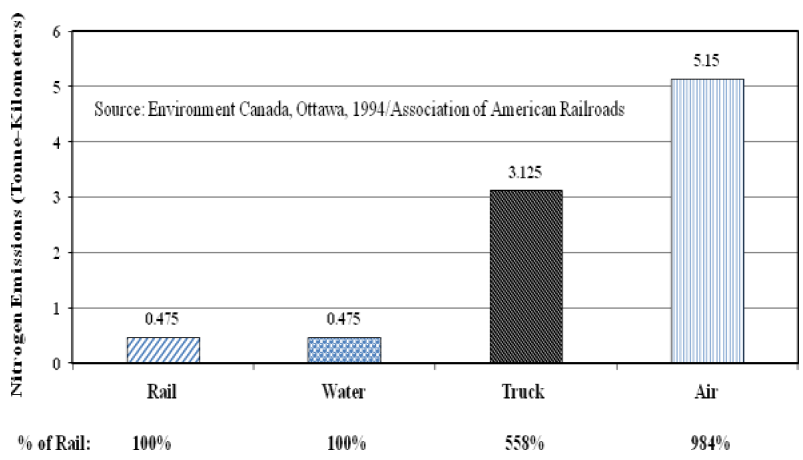

Fig. 2. Modal comparison of freight transport emissions.

\section{Objective}

The primary objectives of this study are to:

(1) Review congestion issues in cities and urban areas, transportation related GHG emission concerns, and air quality impacts.

(2) Demonstrate effectiveness of value engineering approach to evaluate life cycle costs and benefits for justifying less polluting sustainable intermodal transport infrastructure management strategies in cities and metropolitan areas.

\section{Needs for sustainable intermodal transport management}

Since the industrial revolution, the world population has been continuously urbanized as people migrate from rural areas to cities. About $80 \%$ of the current population in industrialized countries lives in densely populated cities and metropolitan areas occupying a very small fraction of the available land area. The developing countries are showing similar trends with $50 \%$ population in cities and more megacities are now outside North America and Europe. With good governance, cities can deliver economic growth, education, health care and other services more efficiently than less densely populated rural areas simply because of their advantages of scale and proximity of infrastructure and job market. Cities also present opportunities for social mobilization, women's empowerment, and cultural diversity. Moreover, higher density of urban populated areas can relieve pressure on surrounding natural habitats and areas of biodiversity if sustainability goals are given priority in infrastructure asset management and transportation planning. The challenge in the next few decades for the future of society depends on learning how to exploit the economic and social benefits urbanization offers without adverse impacts on the environment, which requires developing and implementing sustainable landuse and transport management policies.

Between 1990 and 2007 the U.S. inventory of anthropogenic GHG emission included electricity, transportation, industrial, agricultural, residential, and commercial sectors. The transportation sector accounted for $28 \%$ of all anthropogenic GHG emissions in the U.S. trailing the electricity sector (34\%), followed by industrial (20\%) and agriculture (11\%) sectors [4]. On-road vehicles contribute $81 \%$ of all transportation related GHG emissions in the U.S. in 2004 that increased to $84.5 \%$ in 2008 (Fig. 3). Roads represent the dominant mode of inland traffic in most countries and carry most of the passenger traffic and freight traffic. The deficiency of road infrastructure assets and traffic demand exceeding road capacity 
pose significant challenges to traffic safety and traffic flow management in many cities of developing countries. Frequent congestions and transportation choke points in most urban areas and cities are adversely affecting travel time, business operating costs, and air quality. It is estimated that $75 \%$ of all GHG emissions worldwide are produced by cities and one-third of this is from transportation sources [5]. Increased air pollution (particulate matter particularly) is affecting public health, especially in terms of increase in respiratory diseases and higher mortality rates.

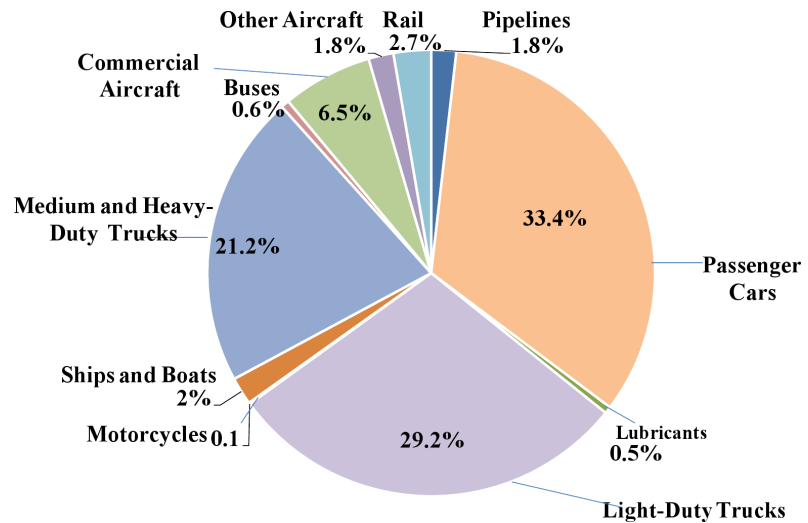

Fig. 3. GHG Emission by Transportation Mode, 2008. (source: US Environmental Protection Agency, 2010).

The measure of the amount of $\mathrm{CO}_{2}$ released, as well as other vehicle emissions, is dependent on traffic demand, driving patterns, traffic flow, congestion hours, vehicle-miles traveled, traffic speeds, and vehicle characteristics. Figure 4 shows that road traffic related emission is higher per capita for several rural and smaller cities compared to large metropolitan areas in the United States and other megacities in developing countries [5].

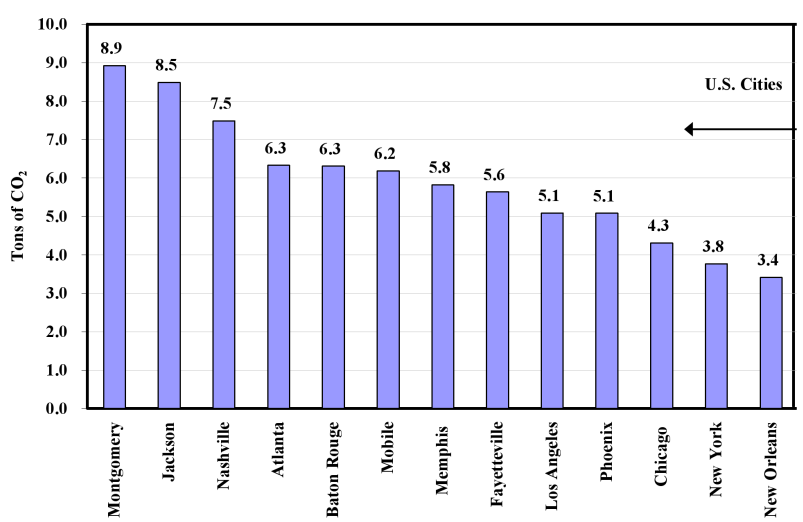

Fig. 4. Annual Per Capita $\mathrm{CO}_{2}$ Emissions from Road Traffic in Selected U.S. Cities for 2007.

A metropolitan area includes both urban area and rural area that are socially and economically in- tegrated with a particular city. Urban sprawl in both metro and non-metro cities destroys parks, agricultural land, forestland, and open spaces. Additionally, it leads lots of city population at risks of flood and other natural hazards. Furthermore inadequate use of mass transit, increasing urban sprawl, deforestation, building more roads and intersections, and adding more lanes to increase capacity and ease congestion are primary causes of increased vehicle emissions of $\mathrm{CO}_{2}$ and air quality degradation.

\section{Sustainability goals and traffic management challenges for cities and intercity travel}

Sustainability is broadly defined as a preservation, development, and traffic management measure that meets the needs of the present without compromising the ability of future generations to meet their own needs. Sustainability goals with respect to intercity travel of people and freight, city infrastructure, and the environment are:

- Enhancing health, Safety and Security;

- Conserving Energy and Enhancing the Environment;

- Creating Equitable and Livable Communities;

- Promoting Economic Prosperity.

Table 1

GHG Emissions by Mode of Transportation in the U.S., 1990-2004 (Source: Transportation Research Record 2017, The National Academies, Washington, DC).

\begin{tabular}{c|lc}
\hline $\begin{array}{c}\text { Transport } \\
\text { Mode }\end{array}$ & \multicolumn{1}{|c}{$\begin{array}{c}\text { Travel and GHG Emission } \\
\text { Indicators }\end{array}$} & $\begin{array}{c}\% \\
\text { Change }\end{array}$ \\
\hline \multirow{2}{*}{$\begin{array}{c}\text { Road - Light } \\
\text { Duty Vehicles } \\
\text { (cars and } \\
\text { trucks) }\end{array}$} & $\begin{array}{l}\text { Vehicle Miles Traveled } \\
(\text { VMT) }\end{array}$ & $+37 \%$ \\
\cline { 2 - 3 } & $\begin{array}{l}\text { Fuel Efficiency (offset by } \\
\text { VMT) }\end{array}$ & $+4 \%$ \\
\cline { 2 - 3 } & GHG Emissions & $+23 \%$ \\
\hline \multirow{2}{*}{$\begin{array}{c}\text { Road - Heavy } \\
\text { Duty Vehicles } \\
\text { freight trucks) }\end{array}$} & $\begin{array}{l}\text { Vehicle Miles Traveled } \\
(\text { VMT) }\end{array}$ & $+53 \%$ \\
\cline { 2 - 3 } & Truck Ton-Mile Increased & Yes \\
\hline \multirow{2}{*}{$\begin{array}{c}\text { Aviation - } \\
\text { Commercial } \\
\text { Aircraft }\end{array}$} & Air VMT Emissions & $+62 \%$ \\
\cline { 2 - 3 } & Passenger Load Factor & $+64 \%$ \\
\cline { 2 - 3 } Rail & GHG Emissions & $+14 \%$ \\
\hline \multirow{2}{*}{$\begin{array}{l}\text { Gon-Road) } \\
\text { Water-borne }\end{array}$} & GHG Emissions & $+32 \%$ \\
\hline Pipeline & GHG Emissions & $+25 \%$ \\
\hline
\end{tabular}

Dependence of commuter mobility and freight truck on fossil fuel consumption is definitely not sustainable. Travel demand (number of vehicles and vehicle-km traveled) is at its highest level. Energy demand is also at its highest level. Fossil fuel sources are diminishing, greenhouse gas emissions are reaching to an extremely high level, and migration from rural areas to urban areas and mobility needs are 
all accelerating these adverse impacts on the environment. Table 1 shows significant increase in road traffic indicators and associated GHG emissions compared to other transport modes. Due to significant fuel efficiency in modern aircraft aviation emission dropped to $1 / 6^{\text {th }}$ of heavy-duty freight trucks.

In 2003, congestion in the top 85 U.S. urban areas caused 3.7 billion hours of travel delay and 2.3 billion gallons of wasted fuel, for a total cost of $\$ 63$ billion [6]. An average of 15 gallons fuel was wasted per person and 25 hour delay per person per year was contributed due to congestion in 2003.

There is a strong need to implement sustainable transportation management policies for reducing dependence on fossil fuel, resulting emissions, congestion, and crashes [7].

It is evident that a reduction of work-related travel by deploying mass and public transit can remove thousands of single occupancy vehicles from roads during peak hours and decreases $\mathrm{CO}_{2}$ and other vehicle emissions in cities. Integrated intermodal transport management strategies to reduce single occupancy vehicles on roads in cities include underground and surface electric powered track-based metro integrated transit buses. As shown in Fig. 5, 132 cities worldwide have implemented metro transport infrastructure networks and/or are expanding their metro networks [8]. This figure shows that 23 cities have 0.5 million or more people riding metro systems annually.

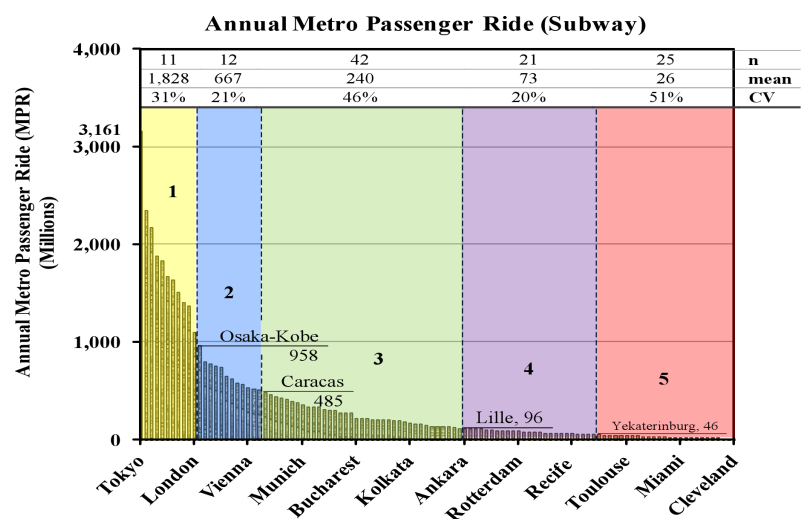

Fig. 5. World Annual Metro Passenger Ride in Million.

Table 2 shows selected 16 cities ranked in descending order from the highest annual metro ride in millions. The Tokyo Subway and Moscow subway systems are the top two most highly used rapid transit system in the world. Moscow, Hong Kong, and Guangzhou are the top three cities with the largest $\%$ of population riding metro [8]. Only two American cities of New York and Washington DC are listed in the table. New York City has $22.6 \%$ of 19.4 million population who rides the metro.

Table 2

World's Selected 16 Cities Ranked in Descending Order from The Highest Annual Metro Ride.

\begin{tabular}{c|lr|c}
\hline Rank & \multicolumn{1}{|l|}{ City, Country } & (Annual metro ride) & \%Pop. \\
\hline 1. & Tokyo, Japan & $(3,161$ million $)$ & 23.6 \\
\hline 2. & Moscow, Russia & $(2,348$ million $)$ & 61.0 \\
\hline 3. & Shanghai, China & $(1,884$ million $)$ & 31.1 \\
\hline 4. & Beijing, China & $(1,840$ million $)$ & 40.7 \\
\hline 5. & Guangzhou, China & $(1,640$ million $)$ & 50.6 \\
\hline 6. & New York City, USA & $(1,604$ million $)$ & 22.6 \\
\hline 7. & Paris, France & $(1,506$ million $)$ & 39.4 \\
\hline 8. & Mexico City, Mexico & $(1,410$ million $)$ & 20.0 \\
\hline 9. & Hong Kong, China & $(1,366$ million $)$ & 53.0 \\
\hline 10. & London, UK & $(1,107$ million $)$ & 35.1 \\
\hline 11. & Săo Paulo, Brazil & $(754$ million $)$ & 10.2 \\
\hline 12. & Singapore & $(745$ million $)$ & 42.2 \\
\hline 13. & Delhi, India & $(460$ million $)$ & 5.7 \\
\hline 14. & Washington, DC, USA & $(217$ million $)$ & 13.3 \\
\hline 15. & Bangkok, Thailand & $(64$ million $)$ & 2.5 \\
\hline 16. & Istanbul, Turkey & $(56$ million $)$ & 1.5 \\
\hline & \multicolumn{2}{r}{}
\end{tabular}

Most other American cities show relatively low metro ridership considering their large populations. However, Moscow metro ridership constitutes the highest at $61 \%$ of 10.5 million population. This indicates a large network of metro system in Moscow with most people using it. Moscow and Tokyo are good examples of sustainable clean mass transit, which lead to smaller carbon footprint per capita in these cities.

São Paulo metro administration in Brazil has embarked upon a traffic management plan to provide fossil fuel-free mass transit transport to its citizen within five years. This plan includes expanded metro subway lines, mono rail line, ground rail line, dedicated bus rapid transit road lanes, and privately owned networks of bus lines [8]. This is the only example of an integrated intermodal transport network in the world where commuters buy one electronic ticket that can be seamlessly used in any one of these modes.

These sustainable and efficient transportation management practices provide clean, sustainable, and safe mobility needs in large cities. Most past transportation projects and city planners did not fully consider the interaction of transportation infrastructure planning with the landuse planning \& built environment and their adverse impacts on air quality and GHG emissions. 


\section{Managing transportation systems}

\section{Life cycle or "whole life" approach}

Life cycle or "whole life" approach was used first time in the 1997 pioneering book Infrastructure Management System by Hudson, et al. [9]. This approach integrates design, construction, renovation and life cycle maintenance phases of physical systems serving the society including transportation infrastructure assets. Figure 6 shows why life cycle assessment is important considering in-service life has the largest influence on life cycle infrastructure costs [9], which will be even higher if non-sustainable transport assets are promoted with respect to vehicle emissions.

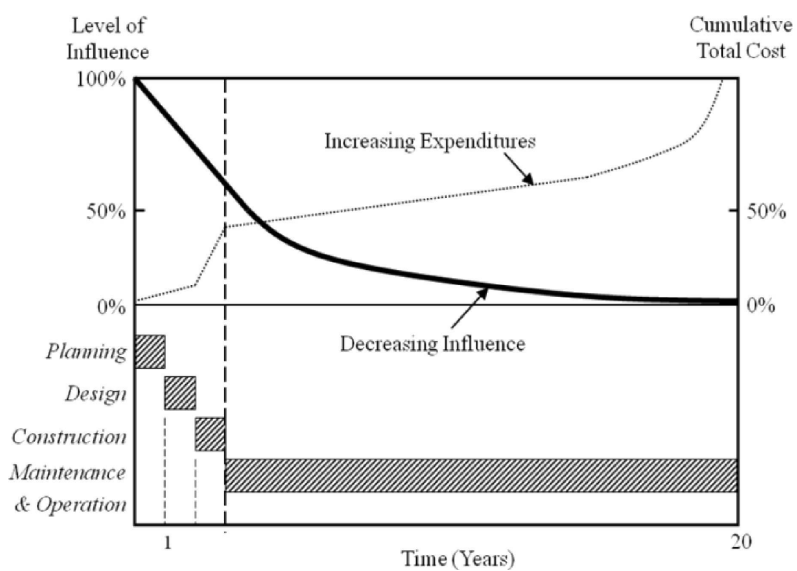

Fig. 6. Influence Levels of Life Cycle Phases on Total Infrastructure Costs.

It is recognized that initial construction costs of track-based underground or elevated electric powered mass transit infrastructure and their integration with intermodal transit transport strategies are several times higher compared to initial construction costs of traditional road transport infrastructure. However, these innovative mass transit assets can be justified based on life cycle cost and benefit comparisons through value engineering approaches because they need less annual maintenance and four times more service life than road infrastructure without any major repair/reconstruction. Also, these electric powered track-based transit services emit zero emissions and are relatively safer than road traffic.

\section{Accounting approach of asset management}

The U.S. Governmental Accounting Standards Board (GASB) initiated a first comprehensive look in 1984 at accounting and reporting of government owned public infrastructure/fixed assets. The GASB 34 statement (GASB 34) promulgated on June 15, 1999 [10] that financial reporting does not require government owned long-lived public infrastructure assets to be depreciated if the assets are:

- Managed using an infrastructure asset management system;

- Preserved at an established condition level.

GSB 34 standard for valuation of public capital assets in the U.S. was implemented by the U.S. DOT Federal Highway Administration (FHWA) for reporting of transportation infrastructure asset valuation and condition [10]. Since the implementation of GASB 34 standards in the $21^{\text {st }}$ century by U.S. highway agencies and municipal public works agencies, emphasis on documenting and reporting of financial/accounting information has been placed. Figure 7 shows GASB valuation framework of infrastructure asset management [after 10]. It requires that an infrastructure asset management system should include an inventory of assets and condition assessment at least every three years. The results of the three most recent assessments should show that the infrastructure assets are being preserved at or above the established condition level.

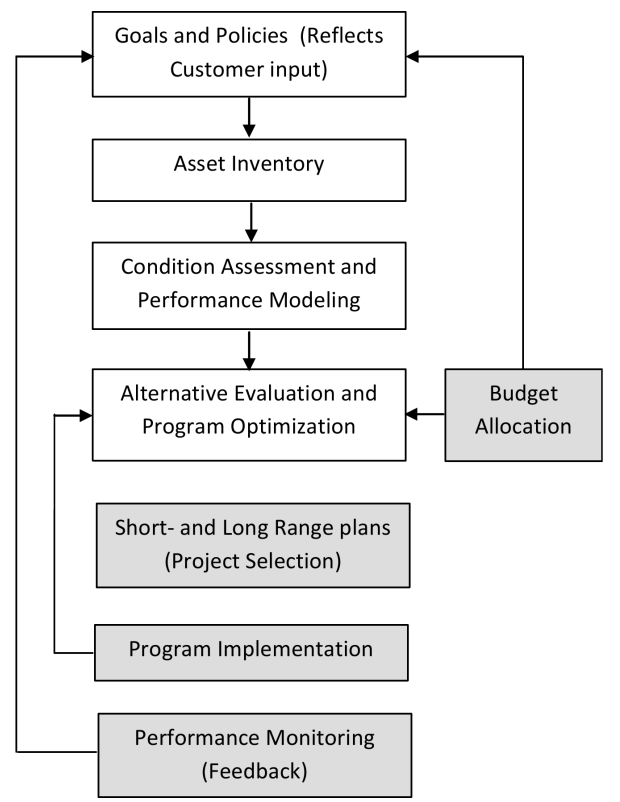

Fig. 7. A General Asset Management Framework. Adapted from Asset Management Primer, Federal Highway Administration, 2000 [10].

\section{Sustainable infrastructure asset management}

Increasing energy demand, diminishing natural resources, raising air pollution, growing GHG emissions, and preserving the environment are current issues of public awareness and general concerns worldwide [5]. Sustainability takes a center page in terms of reducing GHG emission after the 1999 Kyoto Pro- 
Management and Production Engineering Review

tocol and subsequent international accords. The latest accord on June 19, 2012 in Rio de Janeiro eventually endorsed a global plan of action for sustainable development and transportation. The sustainability emphasis is not considered in the infrastructure asset management discussed in the preceding section. Metro and other mass transit modes produce less emission than cars and are, therefore, more sustainable. Asset management considering sustainability dimensions are discussed in detail by Uddin et al. [11].

\section{Value engineering analysis}

\section{Basic principles and overview}

Value Engineering (VE) enables to evaluate a cost-effective management strategy by selecting alternative technologies and methods to achieve reduction in overall life cycle costs without compromising safety and functional performance. Originally implemented by General Electric and defense industries in early 1950's in the U.S., VE has been used to implement innovative materials and methods, reduce cost, and enhance efficiency by manufacturing and production engineering entities. The VE implementation by FHWA is the U.S. started in early 1970s, as summarized by Jackson [12]:

- After VE section was included in Title 23, FHWA initiated VE training program for state highway agencies in 1973-1975.

- National Highway System (NHS) Act of 1995 mandated VE review for all NHS projects costing over $\$ 25$ million. FHWA's VE regulation implementing law was published February 14, 1997 and a VE program was established to study NHS projects costing more than $\$ 25$ million.

- The 2005 surface transportation legislation of SAFETEALU (Safe, Accountable, Flexible, Efficient Transportation Equity Act - A Legacy for Users) mandated:

- State shall provide a value engineering analysis for each project on the Federal-aid system with an estimated total cost of $\$ 25$ million or more.

- A bridge project with an estimated total cost of $\$ 20$ million or more: and

- Any other project the Secretary determines to be appropriate.

- Contractors were allowed to propose innovative alternative materials and methods through Value Engineering in Construction Project (VECP) studies.
Accomplishments of VE projects in the U.S. are summarized in Table 3 for federal Fiscal Year (FY) $2005[12]$.

Table 3

FHWA's VE Project Accomplishments, 2005.

\begin{tabular}{l|l|l}
\hline Item & NHS & Florida \\
\hline No of VE studies & 298 & 3 \\
\hline Cost of VE studies & $\$ 9.42$ Million & $\$ 0.05$ Million \\
\hline Total project cost & $\$ 31.5 \mathrm{~B}$ & $\$ 14$ Million \\
\hline Total \# of recommendations & 2244 & 62 \\
\hline Value of recommendations & $\$ 6.7$ Billion & $\$ 5.8$ Million \\
\hline Approved recommendations & 917 & 1 \\
\hline $\begin{array}{l}\text { Value of approved recom- } \\
\text { mendations }\end{array}$ & $\$ 4.9$ Billion & $\$ 1.3$ Million \\
\hline $\begin{array}{l}\text { Value of approved VECP } \\
\text { projects }\end{array}$ & $\$ 37.3$ Million & $\$ 0.01$ Million \\
\hline
\end{tabular}

The VE approach examines all potential cost items for identifying measures that can reduce life cycle costs without compromise to the function of the item (s) and safety. According to Pareto's law 20\% of the items make up $80 \%$ of the total cost (Fig. 8) which can help to identify construction items for alternative materials.

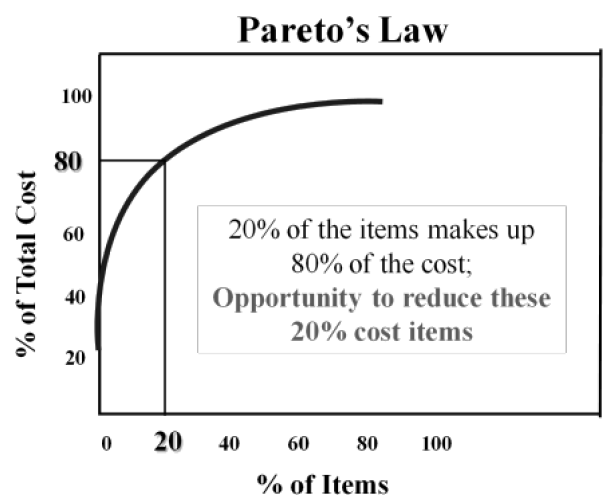

Fig. 8. Illustration of Pareto's Law [after 12].

Some innovative materials and methods first proposed in the VE studies have been accepted in practice. An example is the use of polymeric Fiber Reinforced Plastic (FRP) sheet piles instead of traditional concrete sheet piles by the Florida DOT to protect coastal roads from hurricane destruction (Fig. 9), first presented in the $2006 \mathrm{VE}$ workshop [13].

Installation of innovative non-corrosive lightweight polymeric FRP sheet piles is easier and 3-4 times faster than concrete sheet piles. Based on the results of a value engineering study the overall cost was reduced by one-third. The FRP sheet pile, as an alternative to traditional concrete sheet pile, has been adapted in the design standards of the Florida DOT and many local government agencies in Florida. 


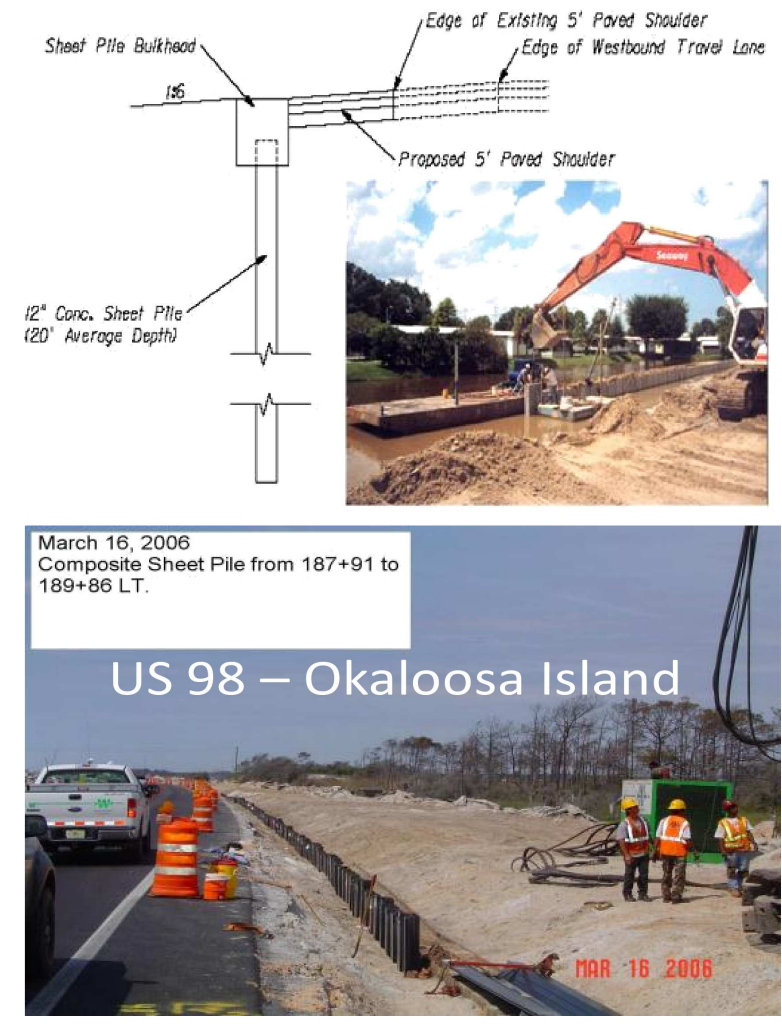

Fig. 9. Traditional Concrete Sheet Piles (top) and FRP Sheet Pile (bottom) Installation (credit: Florida DOT, Kurt Lieblong 2006).

The goals and concerns of VE analysis of infrastructure project designs before bidding and contracting are:

- VE must consider a reduction in overall costs while satisfying all required functions of the project and safe operation.

- VE must show benefits to the users and public.

- VE must minimize adverse environmental, user, and societal impacts.

The economic evaluation requires LCA of cost and benefits for a chosen analysis period for all competing alternatives identified for one or more assets in the $\mathrm{VE}$ process of design review.

\section{Life Cycle Assessment of Costs and Benefits}

The major initial and recurring costs over the life cycle that a public agency may consider in the Life Cycle Assessment (LCA) of project alternatives include the following:

- Ownership and operating/maintenance costs (agency costs);

- Engineering and administration costs;

- Initial capital costs of construction;

- Future costs of maintenance, rehabilitation, and reconstruction;
- Cost of maintenance and protection of traffic;

- Salvage return or residual value at the end of the period ("negative cost");

- Costs of borrowing (for projects not financed from allocated public funds or toll revenues);

- User costs related to service interruptions and time delays;

- Pricing/service costs.

The following benefits are traditionally considered in LCA calculations:

- Benefits in terms of additional taxes or total revenue generated;

- Reduction in service interruption costs;

- Direct reductions in life-cycle costs.

Additionally, the following societal benefits can be considered if sustainability goals are considered in infrastructure investment decision-making process.

- Reduction in congestion, waste of fuel, and air pollution;

- Reduction in GHG and other harmful emissions;

- Reduction in air pollution related public health medical costs;

- Reduction is lost productivity due to emissions and smog;

- Societal savings due to a reduction in carbon surcharge cost.

Emission related public health impacts resulting from urban energy consumption and transportation assets are significant. The related public health costs are significantly higher than typical road user and non-user costs traditionally used for evaluating alternative transportation strategies. Reducing congestion will result in reduction of wastage of fuel. However, life-cycle benefits are large from such savings. As a result, sustainable transportation policies enhance socio-economic prosperity, investment decision-making, public health, and the environment. These societal benefits are especially important if innovative intermodal integration strategies are considered for cities and intercity transport infrastructure for the purpose of achieving goals related to sustainability and reducing adverse impacts of single occupancy vehicles on the environment.

The LCA for a given analysis period is conducted as present worth analysis by discounting the life-cycle costs and benefits to the present value of dollars. Two different present worth factors used in the combined LCA equation; one to discount a single future amount and the other to discount a series of annual future amounts to present worth.

Example: The present worth life cycle cost $(\mathrm{P})$ of a public transit bus project will acquire buses for a service life of (n) years, with an initial cost $(\mathrm{C})$, a 
yearly maintenance cost $(\mathrm{M})$, and a salvage value $(\mathrm{S})$ is equal to:

$$
\mathrm{P}=\mathrm{C}+\mathrm{M}\left[\frac{(1+\mathrm{i})^{\mathrm{n}}-1}{\mathrm{i}(1+\mathrm{i})^{\mathrm{n}}}\right]-\mathrm{S}\left[\frac{1}{(1+\mathrm{i})^{\mathrm{n}}}\right],
$$

where $\mathrm{C}$ - Initial bus fleet cost $=\$ 1,000,000$ for 10 buses (at $\$ 100,000$ per bus), M - Maintenance costs $=\$ 3,000 /$ per year, $\mathrm{S}-$ Salvage value $=\$ 200,000$.

Assume an analysis period (n) of 10 years and an annual discount rate (i) of $5 \%$ to calculate present worth.

$\mathrm{P}=1,000,000+3,000(7.72217)-200,000$ (0.6139),

$\mathrm{P}=1,000,000+23,165-122,780$,

$\mathrm{P}=\$ 900,385$ (present worth of all life-cycle agency costs).

Similarly, present worth benefits (B) of the bus option can be calculated over 10 years, which will include annual bus fare revenue. The benefit-cost ratio $(\mathrm{B} / \mathrm{P})$ is one way of ranking the alternatives where the alternative with the highest ratio is given top rank. Net Present Value (NPV) is another way of ranking alternatives where NPV is the difference of $\mathrm{B}$ and $\mathrm{P}$, which is used to rank alternatives from the highest to the lowest NPV value.

\section{Transportation management strategies to mitigate traffic congestion and emission engineering analysis}

\section{Sustainable Transport Infrastructure Solutions}

Uddin [5] suggests several transportation management strategies for achieving goals of sustainable transport infrastructure, which include the following:

- Reducing congestion, user delays, and wastage of fuel in queues.

- Improving mobility using multimodal approach as a part of space planning concept.

- Using transit modes operating on alternative less polluting energy.

- Increasing mass transit mode share by increasing car parking prices.

- Improving traffic flow management using video surveillance and other Intelligent Transportation System (ITS) technologies to reduce gridlocks, delays, and emissions.

- Evaluating and implementing less polluting and more efficient rail and pipeline solutions for freight transport in place of current dependence on highway trucks. The diesel gulping trucks are highly polluting and emit several times more GHG emissions than alternative freight rail mode. This strat- egy will also require the construction and management of intermodal facilities.

- Increasing revenues by collecting higher fuel taxes on gasoline and diesel.

- Creating new financing opportunities by collecting transportation related carbon emission tax from trip makers by providing incentives of no such tax for commuters who predominantly use transit.

- Constructing more green spaces and promoting non-motorized cycling and pedestrian walking.

- Monitoring air quality and striving for less air pollution and clear skies.

- Reducing backlog of infrastructure and preserving state of good repair.

- Serving more people and creating/preserving jobs.

\section{Atlanta Case Study for Citywide Pollution Mitigation Efforts}

The Georgia Department of Transportation (GDOT) implemented Travel Demand Model (TDM) in Atlanta, Georgia, which has been a nonattainment urban area for many years due to higher level of air pollution. The success of its program in reducing congestion and GHG emissions is due to the use of reliable performance metrics to pitch its messages to the public [14]. For example, the Clean Air Campaign (CAC), a not-for-profit corporation that was formed in 1996 by collaboration of government, business, and civic organizations [14]. The CAC began to conduct employer outreach in 2000 by focusing on travel behavior through informed decisions and public education campaigns. The most effective TDM marketing programs involve a variety of partners within a community, including public officials, community organizations, and individuals support transportation alternatives. Through community based TDM efforts transport network in Atlanta metro area boasts a significant annual reduction in pollution and other benefits each year [14]:

- 16 Million car trips eliminated from metro Atlanta roadways;

- More than 200,000 tons of pollution not released into the air;

- More than $\$ 156$ million estimated in reduced commute costs;

- $\$ 30$ million estimated in health related costs savings due to improved air quality.

\section{New York City's Sustainability Management Initiatives}

New York City, leading by example, set public policy goals to reduce citywide carbon emissions by 30 percent below 2005 levels by 2030 [15]. Table 3 
compares $\mathrm{CO}_{2}$ equivalent $\left(\mathrm{CO}_{2} \mathrm{e}\right)$ per capita emission for several U.S. cities and London. The City is making concentrated effort to reduce transportation emission that in 2005 represented $23 \%$ of total emissions. Total auto trips transport $55 \%$ of people using motorized transport mode, contribute to $78 \%$ of transportation emissions, and generate $18 \%$ of overall $\mathrm{CO}_{2} \mathrm{e}$. The City is promoting mass transit, bike lanes, and alternative fuel vehicles to reduce auto trips, as well as other sectors.

Table 4

Comparison of New York City's GHG Emission Footprint with Other Cities, 2005 [15].

\begin{tabular}{l|c}
\hline City & $\mathrm{CO}_{2}$ e ton per capita \\
\hline London, UK & 5.9 \\
\hline Toronto, Canada & 9.6 \\
\hline New York City, USA & 7.1 \\
\hline San Diego, USA & 11.1 \\
\hline San Francisco, USA & 11.2 \\
\hline USA-National & 24.5 \\
\hline
\end{tabular}

\section{Hypothetical Case Study}

\section{for a Sustainable Transport Infrastructure}

In metropolitan cities and urban areas dedicated elevated Personal Rapid Transit (PRT) pathways provide a sustainable solution to the urban commute and congestion by maximizing the use of existing right-of-ways of public roads [16]. This requires the selection of the "right" PRT vehicle technology that can be light weight, energy efficient, and electronically controlled. The PRT infrastructure requires the use of elevated pavements and bridge structures. Additionally, PRT operations are designed to reduce congestion and impacts on the environment by using efficient cleaner energy sources of electricity and magnetic levitation (Maglev) technology. Examples are Swedish SkyCab (electricity driven) and Brazilian Cobra Maglev vehicle/track systems [17].

The VE analysis involves determination of economic cost of such innovative mass transport technology is derived from a study of the traffic volume data for new lines, users' time savings, number of users willing to pay for such transport alternative, release of capacity on congested roads, and broader economic benefits including development of less developed regions and job creation. The life cycle economic evaluation includes several financial considerations such as present worth analysis of construction, maintenance, and operation costs and benefits over a reasonable analysis period. The LCA considers an appropriate discount rate and calculates net present value of minimum two alternatives. The base alter- native is "do-nothing," and the reduction in user delay hours, less waste of fuel, and decreased emissions are considered indirect benefits from the new alternative transit strategy. The following VE example of a hypothetical case study is for a sustainable transit strategy.

To illustrate life cycle benefit and cost analysis of a PRT system the following benefits and costs are calculated and compared with the base alternative:

1. Base Alternative is Do-nothing for the existing network of roads. Assume 0\% discount rate and analysis period of 10 years.

- This will require milling and repaving asphalt roads at $\$ 1.5$ million US $\$$ per $\mathrm{km}$ or 15 million for $10 \mathrm{~km}$ roads every 5 year. The construction/maintenance cost over in 10 years is 30 million dollars.

- The added user costs due to road maintenance will be $\$ 0.20$ per veh-km. The total added user costs is $(0.20 \times 100,000$ vehicles $\times 10 \mathrm{~km} \times 10$ years) or 2 million dollars over 10 years.

- User delay cost due to congestion hour delays of 25 hours per year per person at $\$ 16$ per hour for $0.5 \%$ traffic volume during peak hours is $(0.005 \times 100,000$ vehicles per day $\times$ 25 hours $\times 16 \$ /$ hour $\times 365$ days per year $\times$ 10 years) or 73 million dollars over 10 years. The cost of waste fuel is ignored in this calculation.

- The total cost over 10 years is $(30+2+73)$ or 105 million dollars. There is zero benefit or a NPV of -105 over 10 years. In 5 years the total cost is 52.5 million dollars and NPV of -52.5 .

2. PRT Alternative: It is assumed that the agency cost for building a 30-40 miles/hour speed PRT system on elevated alignment may cost around 4 million US\$ per km. The PRT's annual operating cost will also be significantly lower than other rail alternative due to energy efficient and light weight vehicle technology.

- The PRT construction cost of $10-\mathrm{km}$ stretch is about 40 million dollars with 0.5 million dollar annual operating and maintenance cost. Or total cost over 10 years is 45 million dollars (at $0 \%$ discount rate).

- Assume that each person using the PRT system saves annually 25 hours of delay at $\$ 16$ per hour and avoids wastage of 15 gallons of fuel and oil at $\$ 3$ per gallon. 
- Therefore, for 20,000 commuters (or $20 \%$ car owners in the daily traffic volume) using PRT instead of driving single occupancy cars, the total user saving is about 9 million dollars annually. The life cycle benefit is 90 million over 10 years (at $0 \%$ discount rate).

- The NPV is equal to 90 minus 45 or 45 million dollars over 10 years. At the end of 5 years the NPV is zero.

3. The PRT alternative is favored in this VE analysis after 5 or more years considering full load rate operation.

This example implies that the PRT's initial construction cost is covered after 5 years (at $0 \%$ discount rate) just by considering annual user saving. Although, this analysis simply ignores passenger fare revenue, that will be an added benefit for owner agency or operator. Additionally, the societal benefit will be significant in terms of reduction in $\mathrm{CO}_{2}$ at 2,765 tons daily or about one million tons annually [18]. Other indirect benefits include less air pollution, reduction in associated public health cost, less risk of on-road crashes, increased productivity, and new manufacturing and service jobs. Identifying and highlighting these indirect benefits to the traveling public and other stakeholders can be a persuasive factor for the approval, funding, and implementation of the PRT system. This makes an attractive case of public-private-partnership investment for this new transport technology.

Environmentally sustainable solutions to mobility require a combination of intermodal integration strategies with reduction in gasoline vehicles on roads and increase in mass transit. Vehicles running on non-fossil fuels such as Natural Gas Vehicle (NGV), biofuel, Maglev, and other energy efficient and less polluting technologies can reduce transportation related harmful emissions and GHG emissions. Building and operating these innovative energy efficient and cleaner mass transit solutions in metropolitan areas and other large cities can be successful, if disincentives are in place to discourage commuters from driving their cars.

\section{Concluding remarks}

Urban areas and cities produce vehicle emissions and demand on energy (due to the increased built areas and population migration from rural areas) with adverse impacts on the environment, both in air quality degradation and increases in GHG emissions. Environmentally sustainable transportation management solutions to mobility require a combination of intermodal integration strategies with reduction in gasoline vehicles, increase in mass transit, and use of non-fossil fuel. The evaluation of the competing transport technologies requires comparison of life cycle costs, user savings, and societal benefits as reduction in emissions. Public-private-partnership investment can be attracted for innovative transport technologies because rate of return is high considering value engineering analysis.

\section{References}

[1] Uddin W., Assessment of Transportation Related Safety and Public Health Impacts Using Remote Sensing and Geospatial Analysis Technologies, Proceedings (Editor: Road Engineering Association Malaysia), 7th Malaysian Road Conference, Kuala Lumpur, Malaysia, 1-16. July 17-19, 2007.

[2] NCFRP, Guidebook for Understanding Urban Goods Movement, Report 14, National Cooperative Freight Research Program (NCFRP), Transportation Research Board, The National Academies, Washington, DC, 2012.

[3] DOT, Highway Statistics 200\%, Federal Highway Administration, U.S. Department of Transportation, Washington, DC. http://www.fhwa.dot.gov/policyinformation/statistics/2007/vm1.cfm Accessed March 9, 2010.

[4] EIA, International Energy Annual Outlook, Energy Information Administration (EIA), U.S. Department of Energy, Washington, DC, 2008.

[5] Uddin W., Mobile and Area Sources of Greenhouse Gases and Abatement Strategies, Chapter 23, Handbook of Climate Change Mitigation, (Editors: WeiYin Chen, John M. Seiner, Toshio Suzuki and Maximilian Lackner), Springer, 2012.

[6] FHWA, Transit and Congestion Pricing, A Primer, FHWA-HOP-09-015, Office of Innovative Program Delivery, Federal Highway Administration (FHWA), U.S. Department of Transportation, Washington, DC, April 2009.

[7] Infrastructure Global, Metros in the World: Providing Clean Mass Transit, Reducing Congestion and Car Emissions in Cities, http://infrastructureglobal.com/metros-in-the-world-providing-clean-masstransit-reducing-congestion-and-car-emissions-incities/ Accessed September 10, 2012.

[8] Infrastructure Global, Sustainable Mass Transit in Cities: Reducing Congestion and Car Emissions in the World by Deploying Metros and Clean Buses, http://infrastructureglobal.com/sustainable-masstransit-in-cities-reducing-congestion-and-caremissions-in-the-world-by-deploying-metros-andclean-buses/ Accessed September 10, 2012. 
[9] Hudson W.R., Hass R., Uddin W., Infrastructure Management, McGraw-Hill, New York, 1997.

[10] Department of Transportation, Primer: GASB 34, Federal Highway Administration, Office of Asset Management, U.S. DOT, Washington, DC, November 2000 .

[11] Uddin W., Hudson W.R., Hass R., Public Infrastructure Asset Management, McGraw-Hill, New York, 2013 (in press).

[12] Jackson Donald R., Assessment of FHWA Value Engineering (VE) Program, Presentation at Value Engineering Best Practices Workshop 156, Transportation Research Board Conference, National Research Council, Washington, DC, January 22, 2006.

[13] Lieblong K., Hurricane Case Studies, Presentation at Value Engineering Best Practices Workshop 156, Transportation Research Board Conference, National Research Council, Washington, DC, January 22, 2006.

[14] NCHRP, State Department of Transportation Role in the implementation of Transportation Demand
Management Programs, Research Results Digest 348, National Cooperative Highway Research Program (NCHRP), Transportation Research Board, The National Academies, Washington, DC, 2010.

[15] New York City Mayor's Office, Inventory of New York City Greenhouse Gas Emissions, New York City Mayor's Office of Long - Term Planning and Sustainability, April 2007.

http://www.nyc.gov/planyc2030 Accessed September 15,2010

[16] Planet Forward, Personal Rapid Transit System: A Solution for Cities, Center for Innovative Media at The George Washington University, Washington, DC. http://planetforward.org/idea/personal-rapidtransit-system-a-solution-for-cities/ Accessed September 15, 2012.

[17] Uddin W., Uddin U., Sustainable Personal Rapid Transit Strategies for Congested Cities And Urban Communities, Proceedings (Editor: Rita Moura Fortes, iSMARTi), 2nd ICTI, International Conference on Transport Infrastructure, São Paulo, Brazil, August 4-6, 2010. 